\title{
Leaf gas exchange and biomass partitioning in Jatropha curcas $L$. young plants subjected to flooding and drought stresses
}

\author{
Tessio Araújo de Santana *, Leandro Dias da Silva ${ }^{2}$, Priscila Souza de Oliveira ${ }^{1}$, Carolina Santos \\ Benjamin $^{3}$, Elmo Pereira Ramos ${ }^{1}$, José Olimpio de Souza Júnior ${ }^{1}$, Fábio Pinto Gomes ${ }^{1}$ \\ ${ }^{1}$ State University of Santa Cruz, Department of Biological Sciences, Ilhéus, Ba 45662900, Brazil \\ ${ }^{2}$ Federal University of Espírito Santo, Department of Plant Production, Alegre, Es 2950000, Brazil \\ ${ }^{3}$ Universidade Federal de Viçosa, Departamento de Fitotecnia, Viçosa, 36570000, Brazil
}

*Corresponding author: tessiosantana@yahoo.com.br

\begin{abstract}
With the purpose of assessing the physiological responses of $J$. curcas young plants to drought and flooding, plants were subjected to three watering regimes: Control, drought and flooding. In the same period, five plants were submitted to drought (irrigation suspension), five to flooding and five were maintained near the field capacity (control). Measurements of leaf gas exchange, chlorophyll content, biomass of each organ (leaf, stem and root), biomass ratios, as well as the root:shoot ratio were made. When compared to control, drought and flooding treatments led to significant reductions $(\mathrm{P} \leq .05)$ of gas exchange rates at 14 and 7 days after imposition treatments (DAIT), respectively. At the $16^{\text {th }}$ DAIT, significant reductions of leaf, root, stem and total biomass were observed, which resulted in changes of biomass partitioning of each organ. Significant reduction of leaf dry biomass (LDB) was observed in water deficit plants. Moreover, no significant effects of water deficit were observed in root dry biomass. Such response has led to a higher root:shoot ratio, suggesting an improved ability for water and nutrients uptake. In turn, flooding has induced a significant decrease in the dry biomass of all organs. Stem dry biomass ratio of flooded plants $\left(0.67 \mathrm{~g} \mathrm{~g}^{-1}\right)$ was significantly higher than that of control plants $\left(0.41 \mathrm{~g} \mathrm{~g}^{-1}\right)$, which, was seemingly due to leaf senescence and root system rotting of flooded plants. Altogether, present results reinforce the susceptibility of the studied genotype of $J$. curcas to flooding, as well as highlight some characteristics of drought tolerance in this species.
\end{abstract}

Keywords: Abiotic stress; biomass allocation; Euforbiaceae; stomatal control; water use efficiency.

Abbreviations: DAIT_days after imposition treatments; DBR_dry biomass ratio; LA_leaf area; LDB_leaf dry biomass; SDB_stem dry biomass ratio; SLA_specific leaf area.

\section{Introduction}

In the current scenario of climate changes, plants are often exposed to various stresses, such as excess (flooding) or deficiency (drought) of water, which may affect their metabolic processes and, consequently growth, development and yield (Chaves and Oliveira, 2004). Flooding-induced plant damage occur, especially by reducing the availability of $\mathrm{O}_{2}$ and the diffusion of gases (mainly $\mathrm{O}_{2}$ e $\mathrm{CO}_{2}$ ) (Perata et al., 2011), inhibiting seed germination, vegetative and reproductive growth and, depending on the intensity, plant death (Kozlowski, 1997). The drought affects many physiological processes of the plants, generally by increasing the stomatal resistance, reducing transpiration and thus the supply of $\mathrm{CO}_{2}$ (Nogueira et al., 2001). Despite the damage caused by this stress, the decrease in stomatal conductance, caused by the limited availability of water, may allow the plant to assimilate more molecules of $\mathrm{CO}_{2}$ for each unit of water transpired, i.e., increased water use efficiency is generally observed in water stressed plants (Blum, 2009). The use of appropriate crops that may grow in such harsh environments is justified (Chaves et al., 2003; Chaves and Oliveira, 2004). Given the climate changes, coupled with need of replacing fossil fuels with renewable fuels, the physic nut (Jatropha curcas L.) has drawn scientific and economic interest. Amongst the advantages of J. curcas over other oilseed crops, one may highlight the high oil production ranging from $30-35 \%$ of seed's weight, the easy conversion of oil into biodiesel, and the lack of competitiveness with the food industry, unlike Glycine max L. and Arachis hypogaea L. (Fairless, 2007). In addition to these agronomic characteristics, J. curcas has been considered tolerant to drought, being reported consistent changes in biomass allocation in favor of root system, allowing them to survive when subjected to water deficit (Achten et al., 2010; DíazLopez et al., 2012; Maes et al., 2009). The hardiness and adaptability of $J$. curcas to different agro-climatic conditions justify its broad distribution (Achten et al., 2008; Divakara et al., 2010) and allows its cultivation in degraded and/or dry climate areas (Srivastava et al., 2011). Based on the possible tolerance of this species to several stressful conditions, we workout the hypothesis that J. curcas can survive, for a determined period, to drought and flooding without significant damage in terms of biomass production. Indeed, there is still the need for a better characterization of the physiological responses of this species when subjected to water stress. Taking into account the above information, this study aimed to evaluate leaf gas exchange and growth responses of $J$. curcas young plants to water stresses by drought and flooding. 


\section{Results}

\section{Changes in leaf gas exchange}

Soil moisture was maintained at around $18.0 \%$ in control pots, whereas irrigation stoppage has led to a moisture decrease from $18.4 \%$ to $10.6 \%$. Water deficiency or excess led to significant $(\mathrm{P} \leq 0.05)$ reductions in gas exchange variables. These reductions were observed from 7 and 14 days after imposition treatments (DAIT) in plants under flooding and water deficit, respectively (Fig 1).

After 16 days under flooding and drought conditions, the plants showed significant reduction in photosynthetic rate (A), with values of 8.0 and $20.7 \mu \mathrm{mol} \mathrm{CO}_{2} \mathrm{~m}^{-2} \mathrm{~s}^{-1}$, respectively, against around $27.1 \mu \mathrm{mol} \mathrm{CO} \mathrm{Cm}^{-2} \mathrm{~s}^{-1}$ in control plants (Fig 1A). Stomatal conductance $(g s)$ was lower in flooded plants, reaching the average value of $0.04 \mathrm{~mol} \mathrm{H}_{2} \mathrm{O}$ $\mathrm{m}^{-2} \mathrm{~s}^{-1}$ at 16 DAIT, i.e., $85 \%$ lower than in control plants (Fig $1 \mathrm{~B})$.

The transpiration rate $(E)$ showed a similar trend. As compared to control plants, those subjected to water deficit and flooding showed reductions of $36 \%$ and $77 \%$, respectively, at 16 DAIT (Fig 1C). Over the same period, the ratio of internal to atmospheric $\mathrm{CO}_{2}$ concentration $(\mathrm{Ci} / \mathrm{Ca})$ was around $46 \%$ of control in water deficit plants, whereas those subjected to flooding showed a reduction of $68 \%$ (Fig 1D).

In this period, regardless of stress, it was observed that the values of $A$ and $E$ had a positive relationship with $g s$ (Fig 2), the reductions in these variables were strongly influenced by decreased $g s$. Despite the marked reduction in $g s$ after irrigation suspension, no corresponding reduction in $A$ was observed. Therefore, higher water use efficiency (WUE) was observed at 16 DAIT in stressed plants (160 and $195 \mathrm{CO}_{2}$ $\mathrm{mol}^{-1} \mathrm{H}_{2} \mathrm{O}$, respectively, in drought and flooded plants), as compared to irrigated plants $\left(102 \mu \mathrm{mol} \mathrm{CO}_{2} \mathrm{~mol}^{-1} \mathrm{H}_{2} \mathrm{O}\right.$ ) (Fig $3)$.

When compared to control plants, it was observed that the instantaneous carboxilation efficiency $(\mathrm{A} / \mathrm{C} i)$ responded differently in stress conditions. While in plants under water deficit, $\mathrm{A} / \mathrm{C} i$ was higher from 14 DAIT. Flooded plants, there was an early (9 DAIT) reduction of these values, around $36 \%$ (Fig 4).

\section{Effect of stress on photosynthetic pigment and growth}

Despite the early response of $J$. curcas to flooding, the chloroplastidic pigment content was not significantly affected $(\mathrm{P} \leq 0.05)$ throughout the period of stress, as well as in plants under drought. It must be noted that, at 16 DAIT, the contents of chlorophylls a, b and total, as well as those of carotenoids were significantly $(\mathrm{P} \leq 0.05)$ higher in plants under drought as compared to flooding and control treatments (Table 1).

The leaf area (LA) of $J$. curcas was negatively affected by the stresses, showing significant $(\mathrm{P} \leq 0.05)$ reductions of $48 \%$ and $84 \%$, in plants under deficit and flooding, respectively, as compared to control. Unlike the effect on LA, drought and flooding led to significant $(\mathrm{P} \leq 0.05)$ increases in specific leaf area (SLA), with increases of $25 \%$ and $51 \%$, respectively (Table 2).

Reduction in total biomass was 47 and $80 \%$, respectively (Fig. 5A). In all treatments, dry biomass ratio (DBR) was peculiar to each organ (Fig. 5B), indicating that the stresses may alter the dry biomass partition in the plants of J. curcas. Although the control treatment has the highest biomass value for all organs, it is possible to observe that leaf DBR value was higher in plants submitted to drought (Figure 5B). This greater contribution of the root in relation to the total biomass of plants subjected to drought is confirmed by the higher root/shoot ratio (R/S) in this treatment $\left(0.16 \mathrm{~g} \mathrm{~g}^{-1}\right)$ (Fig 5B).

\section{Discussion}

Reductions in leaf gas exchange rates are commonly observed in response to water deficit (da Silva et al., 2016; Pompelli et al. 2010; Silva et al. 2010; Tezara et al., 2003) and flooding (Santos et al., 2012; Verma et al., 2012). Stomatal closure is seen as a survival strategy, since it reduces hydraulic conductivity in plants subjected to these stresses reducing transpiration rate, and consequently, water absorption (de Santana et al., 2015; Hubbard et al., 2001; Pezeshki, 2001). As a response to soil flooding, this reduction is common in tolerant as well as non-tolerant to flooding (Kozlowski, 1997). Yet, in tolerant plants, the values are reestablished due to development of hypertrophied lenticels. Such gs recovery was not observed in $J$. curcas plants, as reported for G. americana L., which showed reductions after 14 days even with the emergence of lenticels (Mielke et al., 2003). A species considered tolerant to flooding, Annona glabra L. showed a reduction in $g s$ values from 4 days after the onset of the treatment, and a recovery to values comparable to control after 11 days (Mielke et al., 2005). The authors attributed this recovery to the development of hypertrophied lenticels, together with increased mass allocation to roots.

As opposed to water loss reduction, stomatal closure also reduces the carbon assimilation, thereby causing reduced photosynthetic rate (Chaves et al., 2002). The positive relationship of variables $A$ and $E$ in comparison with $g s$, in $J$. curcas specimens subjected to drought and flooding treatments indicates that stomatal closure may be the major limiting factor of these variables (Cornic, 2000; Sapeta et al., 2013; Silva et al., 2010). This interaction between $g s$ and $E$, shows the importance of controlling stomatal movement (opening and closing), in plants adapted to stress condition, as occured in $J$. curcas plants under water deficit, allowing the plant to maintain a high WUE (Naves-Barbiero et al., 2000; Yang et al., 2005).

Increased $W U E$ in flooded plants results from a known physiological response in which transpiration rate is more affected than carbon assimilation (Medrano et al., 2009). However, the decrease of $W U E$ after 14 days, suggest the occurrence of non-stomatal factor limiting the photosynthetic activity in $J$. curcas. That limitation may be due to lower pigments contents, with great effect on the irradicance uptake capacity (Pezeshki, 2001). Moreover, low rates $\mathrm{A} / \mathrm{Ci}$, observed in flooded plants, suggest the occurrence of biochemical limitation (Silva et al., 2011). Flooding led to reduction of leaf gas exchange variables in contrasting clones of Theobroma cacao for flooding tolerance, but non-stomatal limitation were observed only in the susceptible one (Bertolde et al., 2012). In the present work, non-stomatal limitation to photosynthesis in flooded plants seems to be related more to biochemical constraints (as demonstrated by decreased $\mathrm{A} / \mathrm{Ci}$ ) than to photochemical constraints (as no stress effect on foliar pigment content has been detected).

On the other hand, $\mathrm{A} / \mathrm{Ci}$ was not affected in water deficit plants, which showed even an increase of this variable at the end of experiment, suggesting that photosynthetic limitation in these plants were due to stomatal closure. This characteristic would contribute for a rapid recovery of leaf gas exchange rates upon rewatering, as observed by Pompelli et al. (2010). 
Table 1. Chlorophyll a (Chl a), chlorophyll b $(\mathrm{Chl} \mathrm{b})$, total chlorophyll $\left(\mathrm{Chl} \mathrm{a+b)}\right.$ and carotenoids (Carot) contents $\left(\mu \mathrm{g} \mathrm{cm}^{-2}\right)$ in plants of Jatropha curcas under different water conditions, at 16 days after the imposition of treatment (DAIT).

\begin{tabular}{ccccc}
\hline Treatment & Chl a & Chl b & Chl $(\mathrm{a}+\mathrm{b})$ & Carot \\
\hline Control & $29.41 \pm 1.31 \mathrm{~b}$ & $7.31 \pm 0.33 \mathrm{~b}$ & $36.72 \pm 1.65 \mathrm{~b}$ & $8.07 \pm 0.23 \mathrm{~b}$ \\
Drought & $35.31 \pm 1.25 \mathrm{a}$ & $8.81 \pm 0.32 \mathrm{a}$ & $44.12 \pm 1.57 \mathrm{a}$ & $9.06 \pm 0.20 \mathrm{a}$ \\
Flooding & $25.34 \pm 1.66 \mathrm{~b}$ & $6.28 \pm 0.42 \mathrm{~b}$ & $31.62 \pm 2.08 \mathrm{~b}$ & $7.33 \pm 0.30 \mathrm{~b}$ \\
\hline
\end{tabular}

Different letters indicate significant differences by Tukey test $(\mathrm{P} \leq 0.05)$. Values are means \pm standard error $(\mathrm{n}=5)$.
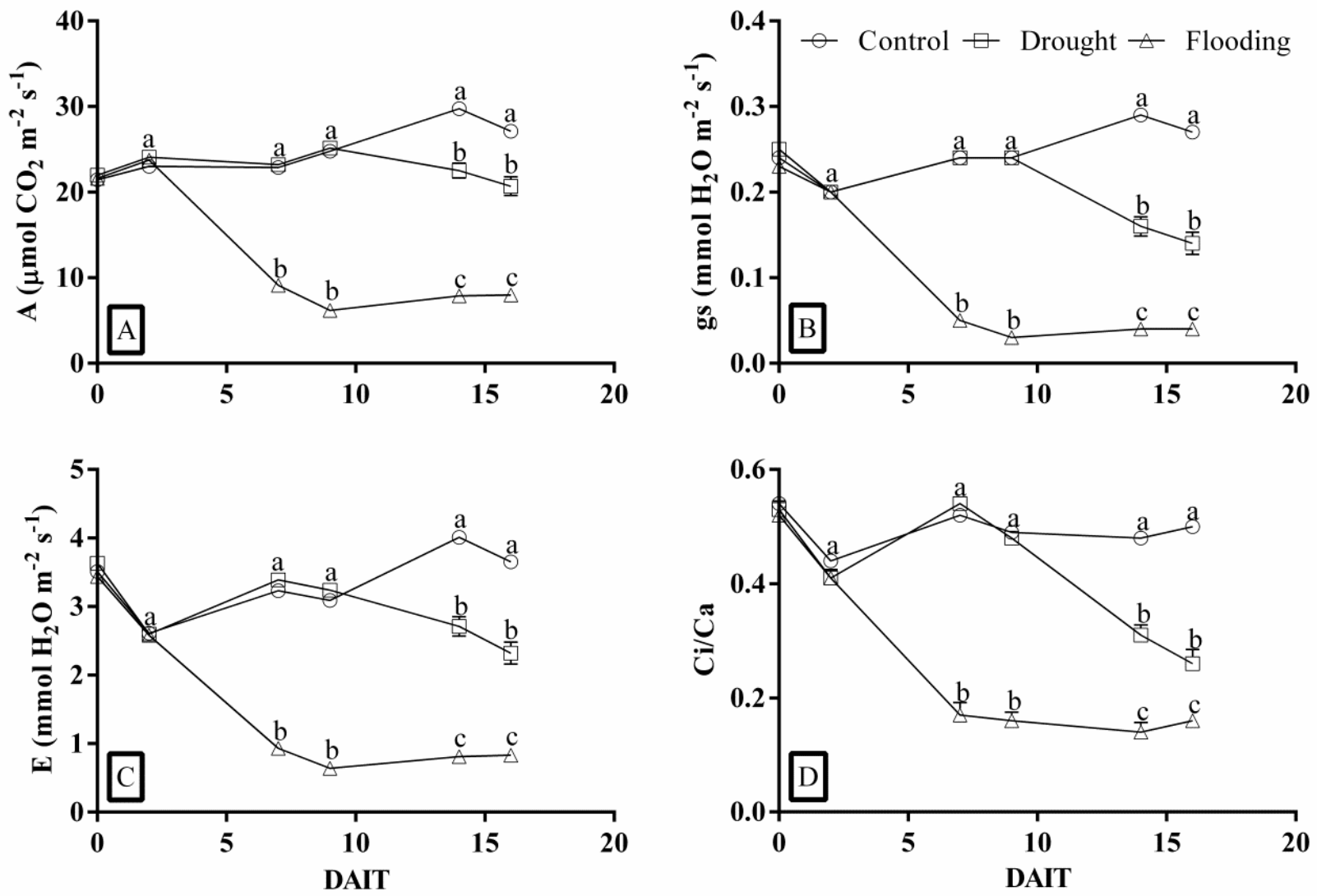

Fig 1. Net photosynthetic rate (A), stomatal conductance (B), transpiration rate (C) and ratio of intercellular to atmospheric $\mathrm{CO}_{2}$ concentration (D) in plants of Jatropha curcas under different water conditions. Different letters indicate significant difference, by Tukey test $(\mathrm{P} \leq 0.05)$, between water regimes. The points represent the mean $(\mathrm{n}=5)$ and the bars indicate the standard error.

Water stress, either by deficiency or excess of water, have provoked leaf dehydration, reduction in growth rate and leaf biomass yield (Else et al., 2001; Liu Stützel, 2004). This study has verified that the effect of stresses on carbon assimilation have caused a more severe reduction in leaf biomass accumulation than in the leaf area. Such response, in turn, was evidenced by a higher specific leaf area in the treatments (drought and flooding) than in the control.

All plants of $J$. curcas survived to 16 days that were subjected to stress, despite decreased biomass production was observed. As described by Achten et al. (2010), the scarcity of water in the soil alters the pattern of biomass allocation of $J$. curcas, favoring the development of root and thereby elevating $\mathrm{R} / \mathrm{S}$ values. The increase in $\mathrm{R} / \mathrm{S}$ enhances the ability of this species in collecting water. Also, the reduction of $g s$ explains the increase in $W U E$ values.

The absence of damage to the root system of $J$. curcas plants subjected to water deficit is an interesting trait for breeding, since it improves the effective use of water, besides influencing the plant's tolerance to stress and preventing reduced productivity (Blum, 2009). Furthermore, these characteristics influence the acclimation of this species to various locations, including areas with limited water availability (Srivastava et al., 2011; Fini et al., 2013).

Leaf senescence and roots decay (Fig 5) were the key factors leading to increase in stem dry biomass ratio (63\% higher than in the control) in $J$. curcas plants subjected to flooding stress, since this increase was not followed by an increase in stem dry biomass (SDB). Negative effects of flooding on the leaf $(62 \%$ reduction) and root $(38 \%$ reduction; in the stem, the reduction was $28 \%$ ) biomass was also observed in $J$.

curcas by Gimeno et al. (2012). According to these authors, this species can be considered sensitive to flooding for about 10 days, with a reduction of $30 \%$ of their total biomass. Such sensitivity has been confirmed in this study, in which $J$. curcas plants, to 16 DAIT, showed reductions of approximately $80 \%$. 
Table 2. Per plant $\left(\mathrm{LA}-\mathrm{cm}^{2}\right)$ and specific (SLA $-\mathrm{cm}^{2} \mathrm{~g}^{-1}$ ) leaf area in plants of Jatropha curcas under different water conditions.

\begin{tabular}{ccc}
\hline Treatment & LA & SLA \\
\hline Control & $1516.4(87.3) \mathrm{a}$ & $217.4(4.2) \mathrm{c}$ \\
Drought & $791.8(35.0) \mathrm{b}$ & $271.0(10.0) \mathrm{b}$ \\
Flooding & $244.7(41.3) \mathrm{c}$ & $328.6(4.0) \mathrm{a}$ \\
\hline
\end{tabular}

Different letters indicate significant differences by Tukey test $(\mathrm{P}<0.05)$. Values are means (standard error) of 5 replicates.
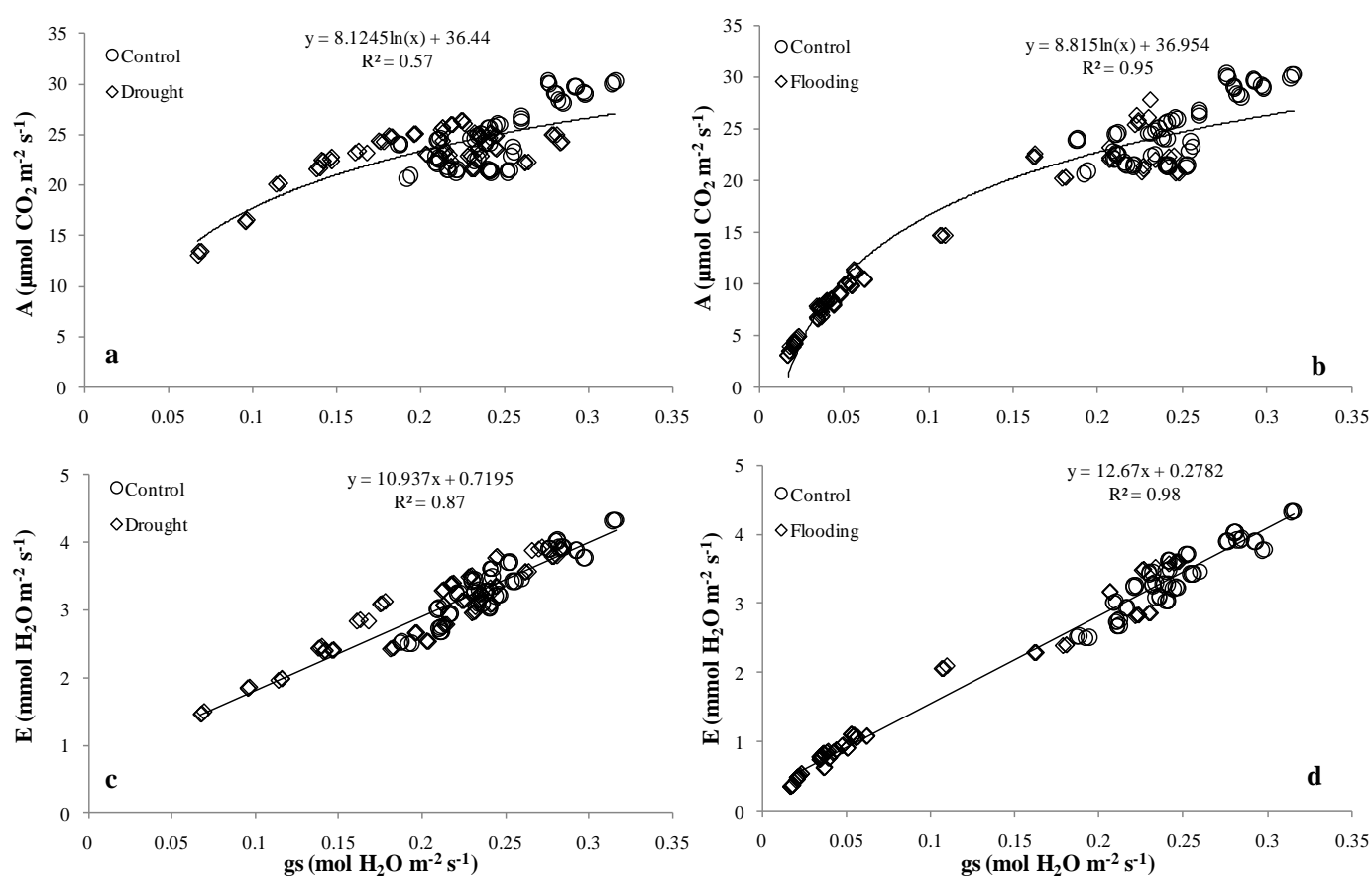

Fig 2. Net photosynthetic rate $(A)$ and transpiration $(E)$ as a function of stomatal conductance $(g s)$, in plants of Jatropha curcas under drought $(\mathrm{a}, \mathrm{c})$ and flooding $(\mathrm{b}, \mathrm{d})$. The points represent the average values of measurements $(\mathrm{n}=5)$.

Table 3. Mean values, maximum and minimum of photosynthetically active radiation ( $\mathrm{PAR}-\mathrm{mol}$ fótons $\mathrm{m}^{-}{ }^{2} \mathrm{day}^{-1}$ ), air temperature (Tair $-{ }^{\circ} \mathrm{C}$ ) and relative humidity $(\mathrm{RH}-\%)$, during the experimental period.

\begin{tabular}{cccc}
\hline Variable & Maximum & Minimum & Mean \\
\hline PAR & 36.4 & 10.1 & 28.3 \\
Tair & 27 & 21 & 23.1 \\
RH & 94 & 58 & 73 \\
\hline
\end{tabular}

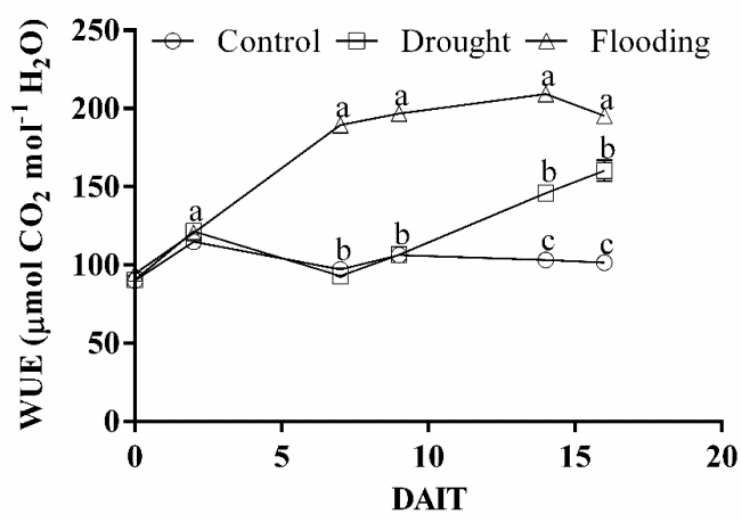

Fig 3. Intrinsic water use efficiency (WUE) in plants of Jatropha curcas under different water conditions. Different letters indicate significant difference, by Tukey test $(\mathrm{P} \leq 0.05)$, between water regimes. The points represent the mean $(n=5)$ and the bars indicate the standard error. 


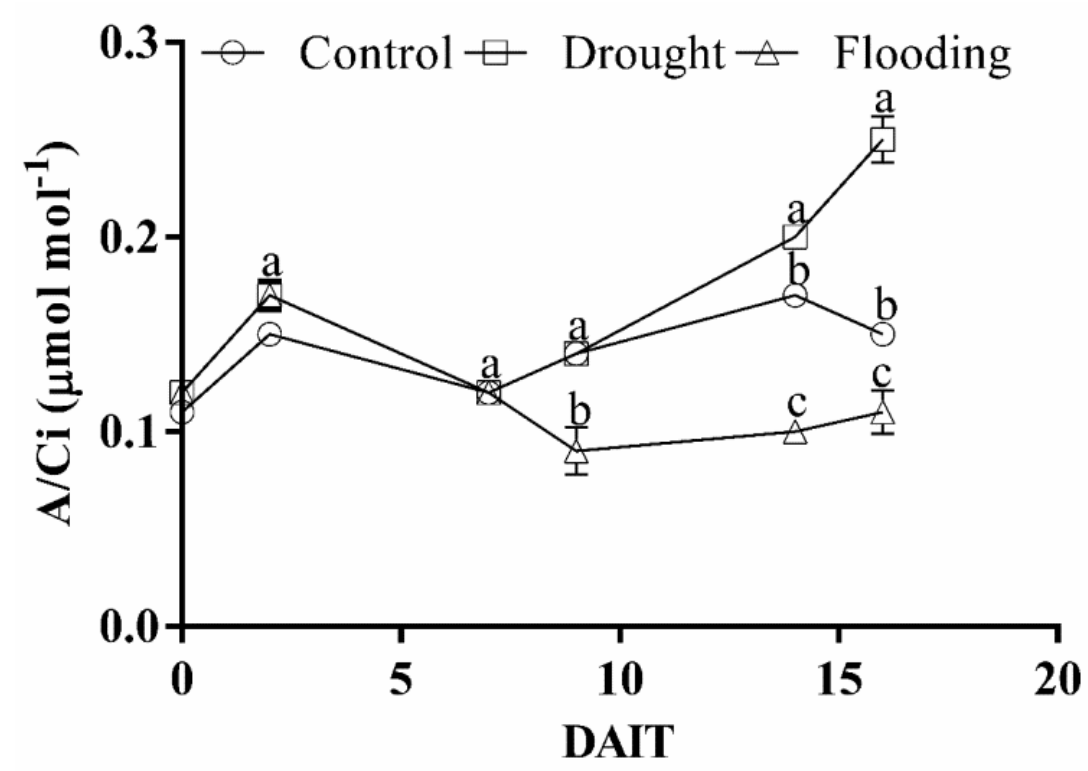

Fig 4. Instantaneous Carboxylation efficiency $(\mathrm{A} / \mathrm{Ci})$ in plants of Jatropha curcas under different water conditions. Different letters indicate significant difference, by Tukey test $(\mathrm{P} \leq 0.05)$, between water regimes. The points represent the mean $(\mathrm{n}=5)$ and the bars indicate the standard error.
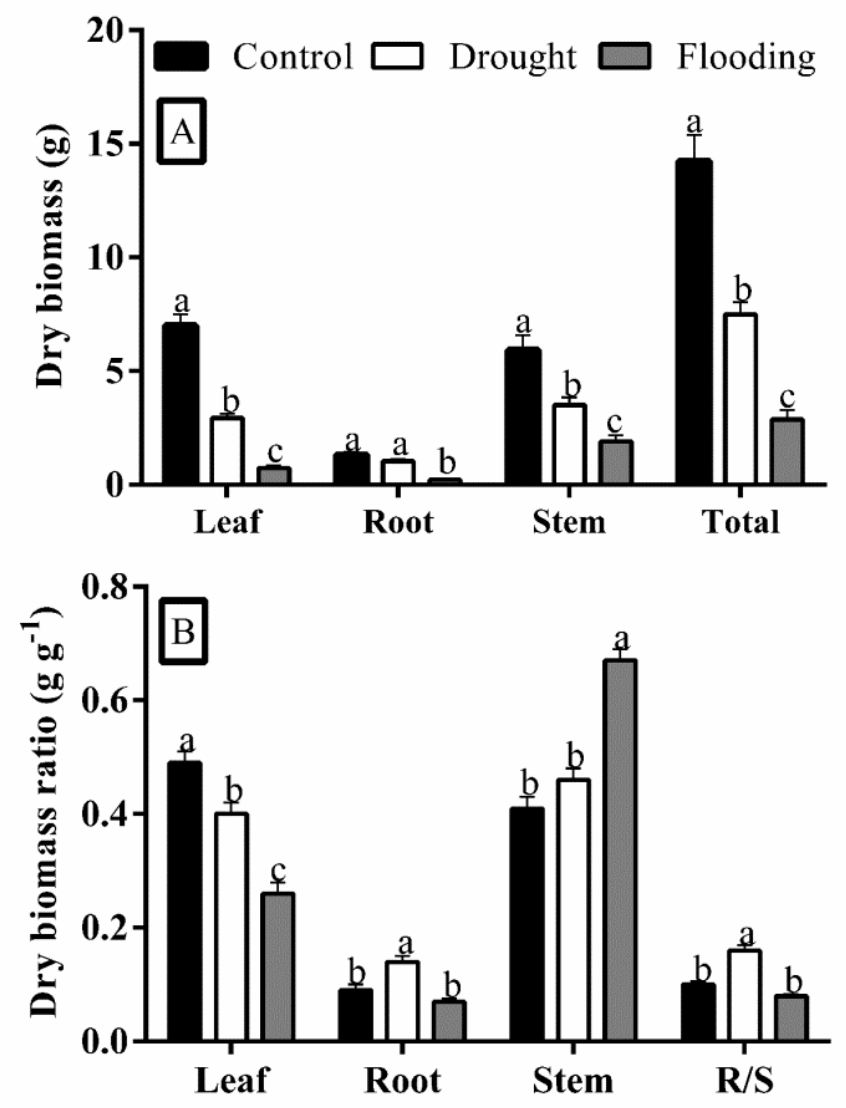

Fig 5. A) Leaf, root, stem and total dry biomass; B) leaf, root, stem dry biomass ratio and root/shoot ratio (R/S) in plants of Jatropha curcas under different water conditions. Columns are means $(n=5)$ and bars are the standard error. 
From these results, it is possible to conclude that flooding has adversely affected leaf gas exchange and biomass production in $J$. curcas. Under water deficit, a high $\mathrm{R} / \mathrm{S}$ associated with to the lower responsiveness of the root system and the effectiveness of stomatal control as strategies for increasing water use efficiency under this stress and surviving to it. Hence, we conclude that these water stresses have exerted a negative effect on $J$. curcas through reductions in gas exchange and biomass production, with sharper decreases in plants subjected to flooding stress.

\section{Materials and Methods}

\section{Plant material and experimental conditions}

A greenhouse experiment was conducted at the campus of State University of Santa Cruz (UESC), in Ilhéus, Bahia,

Brazil. J. curcas seeds, natural of Garanhuns-Pernambuco and donated by Brazilian Agricultural Research Corporation (EMBRAPA), Campina Grande, Paraíba, were germinated in $20 \mathrm{~L}$ pots (six seeds per pot) containing a mixture of soil:sand $(2: 1 \mathrm{v} / \mathrm{v})$. The substrate obtained by the mixture soil:sand showed sandy loam texture and was previously fertilized according to chemical analysis of the substrate. After 15 days of germination, thinning was performed leaving only one plant per pot, constituting the experimental unit. Fifteen days after thinning, the plants were subjected to different water conditions for a period of 21 days. A set of 15 plants were used, five of which were subjected to water deficit, five to flooding and five remained irrigated to pot capacity. The drought treatment consisted of withholding water, whereas flooding condition was obtained by placing the pots into plastic bags, thus preventing drainage, and maintaining the water table above ground level. During the experiment, the photosynthetically active radiation (PAR) was monitored by means of quantum sensors S-LIA-M003, air temperature (Tair) and relative humidity $(\mathrm{RH})$ were monitored using sensors microprocessor Hobo H8 Pro Series (Onset, USA). These variables were measured and stored permanently by data collectors Hobo Micro Station Data Logger (Onset, USA), where the values are shown in table 1.The soil moisture of control and drought plants was determined by the gravimetric method.

\section{Leaf gas exchange}

Leaf gas exchange was measured at $0,2,7,9,14$ and 16 days after the imposition of treatments (DAIT) in one fully mature leaf per plant, using a portable photosynthesis system (LI6400, Li-Cor, Lincoln, NE, USA). Measurements were performed from 8:30 a.m. to 11:30 a.m. under artificial saturating light of $1000 \mu \mathrm{mol}$ photons $\mathrm{m}^{-2} \mathrm{~s}^{-1}$ and atmospheric $\mathrm{CO}_{2}$ concentration $(\mathrm{Ca})$ of $380 \mu \mathrm{mol} \mathrm{mol}{ }^{-1}$. Water use efficiency (WUE) was calculated as the ratio between net photosynthetic rate $(A)$ and stomatal conductance $(g s)$.

\section{Chlorophyll content}

Chloroplastidic pigment content was determined using a portable chlorophyll meter SPAD-502 (Soil Plant Analysis Development, Minolta, Japan), 16 DAIT, in fully mature leaves. From the SPAD index values, we have calculated the concentrations of chlorophyll $\mathrm{a}$ and $\mathrm{b}$ and carotenoids, according to Rigon et al. (2013) for J. curcas.

\section{Biomass}

At the end of the experiment, all the plants were harvested and sectioned in their leaves, stems and roots for dry biomass (DB) analysis. From these values, dry biomass ratio (DBR) of leaf, stem, and root, as well as the root:shoot ratio (R/S) have been calculated. Leaf area (LA) was measured using a leaf area meter (LI-3100, Li-Cor, Lincoln, NE, USA). Specific leaf area was calculated as SLA $=\mathrm{LA} / \mathrm{DB}$ of leaf.

\section{Experimental design and statistical analysis}

A completely randomized experimental design was set, with three treatments (control, flooding and drought) and five replicates for each treatment, totaling 15 plants. The data were subjected to analysis of variance and the means were compared by Tukey test at $5 \%$ significance.

\section{Conclusions}

From these results, it is possible to conclude that flooding has a more pronounced negative effect than water deficit on leaf gas exchange and biomass production in $J$. curcas. Under water deficit, high R/S associated with lower responsiveness of the root system and the effectiveness of stomatal control, can be highlighted as strategies for increasing water use efficiency under this stress and surviving to it. Hence, we conclude that these water stresses have exerted a negative effect on $J$. curcas through reductions in gas exchange and biomass production, with sharper decreases in plants subjected to flooding stress.

\section{Acknowledgments}

Financial support for the investigation was provided by National Council for Scientific and Technological Development, CNPq (Grants 486218/2011-2) and Fundacão de Amparo à Pesquisa do Estado da Bahia - FAPESB (Grants APP0108/2009). The authors were supported by CAPES, CNPq and FAPESB. Fábio P. Gomes gratefully acknowledge the CNPq, Brazil, for the concession of a fellowship of scientific productivity.

\section{References}

Achten WMJ, Verchot L, Franken YJ, Mathijs E, Singh VP, Aerts R, Muys B (2008) Jatropha bio-diesel production and use. Biomass Bioenerg. 32:1063-1084.

Achten WMJ, Maes WH, Reubens, B, Mathijs E, Singh VP, Verchot L, Muys B (2010) Biomass production and allocation in Jatropha curcas L. seedlings under different levels of drought stress. Biomass Bioenerg. 34:667-676.

Bertolde FZ, Almeida A-AF, Pirovani CP, Gomes, FP, Ahnert D, Baligar VC, Valle RR (2012) Physiological and biochemical responses of Theobroma cacao L. genotypes to flooding. Photosynthetica. 50(3):447-457

Blum A (2009) Effective use of water (EUW) and not wateruse efficiency (WUE) is the target of crop yeld improvement under drought stress. Field Crop Res. 112:119-123.

Chaves MM, Maroco JP, Pereira JS (2003) Understanding plant responses to drought - from genes to the whole plant. Funct Plant Biol. 30:239-264.

Chaves MM, Oliveira MM (2004) Mechanisms underlying plant resilience to water deficits: prospects for water-saving agriculture. J Exp Bot 55(407):2365-2384 
Chaves MM, Pereira JS, Maroco J, Rodrigues ML, Ricardo CPP, Osório ML, Carvalho I, Faria T, Pinheiro C (2002) How Plants Cope With Water Stress in the Field. Photosynthesis and Growth. Ann Bot-London. 89:907-916.

Cornic G (2000) Drought stress inhibits photosynthesis by decreasing stomatal aperture - not by affecting ATP synthesis. Trends Plant Sci. 5:187-188.

da Silva LD, de Santana TA, de Oliveira PS, Laviola BG, da Costa MGC, de Almeida AAF, Gomes FP (2016) Abscisic acid-mediated stomatal closure and antioxidant defenses in Jatropha curcas L. seedlings submitted to moderate water deficit. Afr J Agric Res. 11(30):2806-2816.

de Santana TA, Oliveira PS, Silva LD, Laviola BG, de Almeida AAF, Gomes FP (2015) Water use efficiency and consumption in different Brazilian genotypes of Jatropha curcas L. subjected to soil water deficit. Biomass Bioenerg. 75:119-125.

Díaz-López L, Gimeno V, Simón I, Martínez V, RodríguezOrtega WM, García-Sánchez F (2012) Jatropha curcas seedlings show a water conservation strategy under drought conditions based on decreasing leaf growth and stomatal conductance. Agr Water Manage. 105:48-56.

Divakara BN, Upadhyaya HD, Wani SP, Laxmipathi Gowda CL (2010) Biology and genetic improvement of Jatropha curcas L.: A review. Appl Energ. 87:732-742.

Else MA, Coupland D, Dutton L, Jackson MB (2001) Decreased root hydraulic conductivity reduces leaf water potential, initiates stomatal closure and slows leaf expansion in flooded plants of castor oil (Ricinus communis) despite diminished delivery of ABA from the roots to shoots in xylem sap. Plant Physiol. 111:46-54.

Fairless D (2007) Biofuel: The little shrub that could maybe. Nature 449:652-655.

Fini A, Bellasio C, Pollastri S, Tattini M, Ferrini F (2013) Water relations, growth, and leaf gas exchange as affected by water stress in Jatropha curcas. J Arid Environ. 89:2129.

Gimeno V, Syvertsen JP, Simón I, Nieves M, Díaz-López L, Martínez V, García-Sánchez F (2012) Physiological and morphological responses to flooding with fresh or saline water in Jatropha curcas. Environ Exp Bot. 78(3):47-55.

Hubbard RM, Ryan MG, Stiller V, Sperry JS (2001) Stomatal conductance and photosynthesis vary linearly with plant hydraulic conductance in ponderosa pine. Plant Cell Environ. 24:113-121.

Kozlowski TT (1997) Responses of woody plants to flooding and salinity. Tree Physiol. 1:1-29.

Liu F, Stützel H (2004) Biomass partitioning, specific leaf area, and water use efficiency of vegetable amaranth (Amaranthus spp.) in response to drought stress. Sci HorticAmsterdam. 102:15-27.

Maes WH, Achten WMJ, Reubens B, Raes D, Samson R, Muys B (2009) Plant-water relationships and growth strategies of Jatropha curcas L. seedlings under different levels of drought stress. J Arid Environ. 73:877-884.

Medrano H, Flexas J, Galmés J (2009) Variability in water use efficiency at the level among Mediterranean plants with different growth forms. Plant Soil. 317:17-29.

Mielke MS, Almeida A-AF, Gomes FP, Aguilar MAG, Mangabeira PAO (2003) Leaf gas exchange, chlorophyll fluorescence and growth responses of Genipa americana seedlings to soil flooding. Environ Exp Bot. 50:221-231.

Mielke MS, Matos EM, Couto VB, Almeida A-AF, Gomes FP, Mangabeira PAO (2005) Some photosynthetic and growth responses of Annona glabra L. seedlings to soil flooding. Acta Bot Bras. 19(4):905-911.
Naves-Barbiero CC, Franco AC, Bucci SJ, Goldstein G (2000) Fluxo de seiva e condutância estomática de duas espécies lenhosas sempre-verdes no campo sujo e cerradão. Revista Brasileira de Fisiologia Vegetal 12(2):119-134.

Nogueira RJM, Moraes JAPV, Burity HA, Bezerra Neto E (2001) Alterações na resistência à difusão de vapor das folhas e relações hídricas em aceroleiras submetidas a déficit de água. Revista Brasileira de Fisiologia Vegetal 13(1): 75-87.

Perata P, Armstrong W, Voesenek LACJ (2011) Plant and flooding stress. New Phytol. 190:269-273.

Pezeshki SR (2001) Wetland plant responses to soil flooding. Environ Exp Bot. 46:299-312.

Pompelli MF, Barata-Luís R, Vitorino HS, Gonçalves ER, Rolim EV, Santos MG, Almeida-Cortez JS, Ferreira VM, Lemos EE, Endres L (2010) Photosynthesis, photoprotection and antioxidant activity of purging nut under drought deficit and recovery. Biomass Bioenerg. 34:1207-1215.

Rigon JPG, Capuani S, Brito Neto JF, Beltrão NEM (2013) Indirect measurement of photosynthetic pigments in the leaves of Jatropha curcas. Semin-Cienc Agrar. 34(2):669674

Santos TA, Mielke MS, Pereira HAS, Gomes FP, Silva DC (2012). Trocas gasosas foliares e crescimento de plantas jovens de Protium heptaphyllum March (Burseraceae) submetidas ao alagamento do solo em dois ambientes de luz. Sci For. 40(93):47-56.

Sapeta H, Costa JM, Lourenço T, Maroco J, Van der Linde P, Oliveira MM (2013) Drought stress response in Jatropha curcas: Growth and Physiology. Environ Exp Bot. 85:7684.

Silva EN, Ribeiro RV, Ferreira-Silva SL, Viégas RA, Silveira JAG (2011). Salt stress induced damages on the photosynthesis of physic nut young plants. Sci Agric. 68(1):62-68

Silva EN, Ribeiro RV, Viégas RA, Silveira JAG (2010) Comparative effects of salinity and water stress on photosynthesis, water relations and growth of Jatropha curcas plants. J Arid Environ. 74:1130-1137.

Srivastava P, Behera SK, Gupta J, Jamil S, Singh N, Sharma YK (2011) Growth perfomance, variability in yeld traits and oil content of selected accessions of Jatropha curcas L. growing in a large scale plantation site. Biomass Bioenerg. 35:3936-3942.

Tezara W, Martínez D, Rengifo E, Herrera A (2003) Photosynthetic responses of the Tropical Spiny shrub Lycium nodosum (Solanaceae) to drought, soil salinity and saline spray. Ann Bot-London. 92(6): 757-765.

Verma KK, Singh M, Verma CL (2012) Developing a mathematical model for variation of physiological responses of Jatropha curcas leaves depending on leaf positions under soil flooding. Acta Physiol Plant. 34(4):1435-1443.

Yang H-M, Zhang JH, Zhang X-Y (2005) Regulation mechanisms of stomatal oscillation. Acta Bot Sin. 47(10):1159-1172. 